\title{
Climatic Thresholds for Concentrations of Minerals and Heavy Metals in Argentinean Soybean
}

\author{
Carla G. Marioli Nobile,* Mónica Balzarini, Fernando M. Aguate, N. Ruben Grosso, Diego O. Soldini, \\ Huawei Zeng, Wen-Hsing Cheng, and María Jose Martínez
}

\begin{abstract}
Minerals affect the nutritional, rheological, and safety features of food products. Soybeans represent a good source of minerals. The objective of this study was to evaluate the effect of the environment on the variability of mineral elements in Argentinean soybeans in field experiments. Climatic variables (maximum, mean, and minimum air temperature; solar radiation; precipitation; and potential evapotranspiration) were recorded daily during the seed filling period; soil properties were also reported. Minerals in soybeans were determined by inductively coupled plasma-mass spectrometry. Selenium was determined by hydride generation coupled to an atomic absorption spectrophotometer. Molybdenum and selenium were significantly increased (over 100\%) in soybeans grown at higher soil $\mathrm{pH}$ with high available molybdenum. Air temperature was the climatic variable that best predicted changes in the soybean seed mineral composition. Optimum weather conditions (OWC) were defined by thresholds of the climatic variables by regression trees for desirable mineral composition. Maximum and minimum daily air temperatures during the seed filling period $\left(30.1\right.$ and $17.1^{\circ} \mathrm{C}$, respectively) were the OWC for maximizing calcium, magnesium, and manganese contents. A maximum daily air temperature over $28.0^{\circ} \mathrm{C}$ resulted in higher iron and cobalt levels $(p<0.001)$. Maximum zinc content was observed when solar radiation exceeded $18.1 \mathrm{MJ} \mathrm{m}^{-2}$ during seed filling $(p<0.001)$. Results from this study showed variation in the mineral composition of soybeans. Environmental features during the seed filling period should be considered when desired mineral composition is expected in soybean according to the end uses.
\end{abstract}

$\mathrm{M}$ inerals CONSTITUTE the basis of life on earth (Graham et al., 2007), and their absence in the diet leads to unperceived symptoms and severe health consequences. Mineral undernourishment is of concern throughout the world, and plant-derived foods are considered a mineral source to attain an beginadequate daily mineral intake (Graham et al., 2007). Selenium (Se) is sought for nutraceutical properties because it helps to strengthen the immune system. Geographical areas with Se deficiencies have shown higher incidences of diseases (Rayman, 2012). Soybeans are consumed daily by millions of people and animals. Along with proteins and oil, soybeans provide minerals to the diet (Graham et al., 2007).

Minerals also contribute to the properties of end-food products. Iron $(\mathrm{Fe})$, copper $(\mathrm{Cu})$, and manganese $(\mathrm{Mn})$ affect the oxidative stability and shelf life of edible oils (Knothe and Dunn, 2003). Low Ca, Mn, and boron (Bo) contents in soybeans have been associated with improved visual attributes of a popular Asian food called natto (Yoshikawa et al., 2014).

The uptake of heavy metals, such as lead (Pb), cadmium (Cd), and arsenic (As), occurs at the same time the plant is absorbing mineral nutrients (Lavado, 2006). Some heavy metals, such as $\mathrm{Pb}, \mathrm{Cd}$, and As, present in soybeans grown in long-term cultivated areas of the United States (Chen et al., 2009) and Brazil (Corguinha et al., 2015) have been estimated using risk assessment models.

The variability of the concentration of phosphorous $(\mathrm{P}), \mathrm{B}$, $\mathrm{Zn}$, and $\mathrm{Mn}$ in soybean seeds was observed in soybeans grown in different environments, also affecting the mineral content of tofu (Bhardwaj et al., 2007). Jaureguy et al. (2013) reported that there is significant improvement by sowing date interaction for minerals in soybeans. Late sowing dates associated with lower temperatures during seed fill result in a lower average mineral

C.G. Marioli Nobile, Estación Experimental Agroindustrial Obispo Colombres (EEAOC), T4101XAC, Tucumán, Argentina; M. Balzarini and F.M. Aguate, Facultad de Ciencias Agropecuarias (FCA), Universidad Nacional de Córdoba (UNC), Cátedra de Estadística, 5000, Córdoba, Argentina; N.R. Grosso, FCA-UNC, IMVIB-CONICET, 5000, Córdoba, Argentina; D.O. Soldini, Estación Experimental Agropecuaria (EEA) Instituto Nacional de Tecnología Agropecuaria (INTA) Marcos Juárez, 2580, Marcos Juárez, Córdoba, Argentina; H. Zeng, Grand Forks USDA Human Nutrition Research Center, 58203, Grand Forks, ND; W.-H. Cheng, Dep. of Food Science, Nutrition and Health Promotion, Mississippi State Univ., MS 39762; M.J. Martínez, EEA INTA Manfredi, Laboratorio de Calidad de Granos, 5988, Manfredi, Córdoba, Argentina. ${ }^{*}$ Corresponding author (carlagmn@gmail.com).

Abbreviations: CEC, cation exchange capacity; OWC, optimum weather conditions; PLS, partial least squares; PP, precipitation; $\mathrm{REV}$, relative environmental variance; $\mathrm{RT}$, regression tree; SR, solar radiation.
Published in Agron. J. 108:532-539 (2016)

Received 10 Sept. 2015

Accepted 16 Nov. 2015

Copyright (c) 2016 by the American Society of Agronomy 5585 Guilford Road, Madison, WI 53711 USA

All rights reserved 


\begin{tabular}{|c|c|c|c|c|c|c|}
\hline Locations† & Soil & Texture & $\mathrm{pH}$ & Salinity & $\mathrm{OM} \neq$ & CEC $\oint$ \\
\hline & & & & $\mathrm{dS} \mathrm{m}^{-1}$ & $\%$ & $\mathrm{cmol} \mathrm{kg}^{-1}$ \\
\hline BW $\left(38^{\circ}\left|9^{\prime} \mathrm{S} ; 60^{\circ}\right| 4^{\prime} \mathrm{W}\right)$ & Petrocalcic Argiudol & loam & 6.4 & 0.4 & 2.3 & 21.5 \\
\hline $\mathrm{BO}\left(37^{\circ} 49^{\prime} \mathrm{S} ; 63^{\circ} 02^{\prime} \mathrm{W}\right)$ & Typic Haplustol & sandy loam & 6.8 & 0.6 & 1.4 & 14.9 \\
\hline $\mathrm{CE}\left(24^{\circ} 54^{\prime} \mathrm{S} ; 65^{\circ} 29^{\prime} \mathrm{W}\right)$ & Udic Ustocrept & loam & 6.2 & 0.5 & I.I & 10.4 \\
\hline $\mathrm{CA}\left(27^{\circ} 38^{\prime} \mathrm{S} ; 55^{\circ} 30^{\prime} \mathrm{W}\right)$ & Rhodic Kandiudult & loam clay & 5.7 & 0.5 & 2.4 & 28.7 \\
\hline $\mathrm{FA}\left(27^{\circ} 04^{\prime} \mathrm{S} ; 65^{\circ} 25^{\prime} \mathrm{W}\right)$ & Typic Hapludol & loam clay & 6.0 & 0.4 & 1.9 & 11.3 \\
\hline $\mathrm{MA}\left(31^{\circ} 49^{\prime} \mathrm{S} ; 63^{\circ} 46^{\prime} \mathrm{W}\right)$ & Entic Haplustol & loam silt & 6.9 & 0.4 & 2.0 & 19.7 \\
\hline $\mathrm{PA}\left(31^{\circ} 44^{\prime} \mathrm{S} ; 60^{\circ} 32^{\prime} \mathrm{W}\right)$ & Aqcuic Argiudol & loam clay & 6.2 & 0.5 & 3.2 & 30.8 \\
\hline $\mathrm{RQ}\left(29^{\circ} 40^{\prime} \mathrm{S} ; 59^{\circ} 12^{\prime} \mathrm{W}\right)$ & Typic Argiudol & loam clay & 6.2 & 0.3 & 1.5 & 15.5 \\
\hline
\end{tabular}

† BO, Bordenave; BW, Barrow; CA, Cerro Azul; CE, Cerrillos; FA, Famailla; MA, Manfredi; PA, Parana; RQ, Reconquista.

$\ddagger$ Organic matter.

$\S$ Cation exchange capacity.

content (Jaureguy et al., 2013). It has been proposed that higher air temperature promotes higher $\mathrm{Ca}$ content in seeds (Bellaloui et al., 2011; Gibson and Mullen, 2001).

Heterogeneous farmable land of Argentina (20.2 million ha) contributes to approximately $20 \%$ of world soybean production. Several agricultural practices, including crop biofortification, are considered as management tools to enhance mineral composition in staple crops (Graham et al., 2007). For that reason, studying the effect of the environment on mineral composition may help agricultural management efficiency for nutritional purposes. Soybean production is mainly destined for the preparation of food products, and plant foods are the main source of minerals for human and animal nutrition. Addressing the sources of variation in mineral concentration in soybeans may lead to a better understanding of the link between agricultural production and human health (Welch and Graham, 1999). The aim of the present study was to determine the effect of the environmental variables on the variability of mineral elements in Argentinean soybeans evaluated in field experiments. Soil properties and soil minerals were also compared with mineral composition in the soybean seed samples.

\section{MATERIALS AND METHODS}

\section{Soybean Materials and Field Experiments}

Two soybean [Glycine max (L.) Merr.] varieties were use in this study. One of them was ALIM 3.14, which is a breeding line for specialty high-protein and nongenetically modified soybeans developed by the Soybean Breeding Program at Estación Experimental Agropecuaria- Instituto Nacional de Tecnología Agropecuaria. The other one was a commercial transgenic glyphosate-resistant soybean widely used in Argentina (Carrera et al., 2011).

The experimental design and agricultural practices were described in detail by Carrera et al. (2011). Eight locations were selected covering the Argentine soybean cropland from $24^{\circ} 54^{\prime}$ to $38^{\circ} 19^{\prime} \mathrm{S}$ and from $55^{\circ} 30^{\prime}$ to $65^{\circ} 25^{\prime} \mathrm{W}$ (Table 1): Barrow (BW), Bordenave (BO), Cerrillos (CE), Cerro Azul (CA), Famailla (FA), Manfredi (MA), Parana (PA), and Reconquista (RA). Field experiments were conducted on two sowing dates, classified as early and late, with two in-field replicates in a randomized complete block design during the crop seasons 2006-2007 and 2007-2008. Early sowing dates for lower latitudes were between the end of October and the beginning of November and for higher latitudes between the end of November and the beginning of December. Late sowing dates for higher latitudes were between the middle of November and the first days of December and for higher latitudes were between the middle of December and the middle of January. Some environments were lost due to adverse conditions, such as extreme drought, hail, floods, or animal damage.

Maximum, mean, and minimum air temperature $\left({ }^{\circ} \mathrm{C}\right)$; precipitation $(\mathrm{PP})(\mathrm{mm})$; potential evapotranspiration $(\mathrm{mm})$; and solar radiation (SR) $\left(\mathrm{MJ} \mathrm{m}^{-2}\right.$ ) were recorded daily during the seed filling period between the R5 (beginning seed) and R7 (beginning maturity) stages (Fehr and Caviness, 1977). Hydric balance $(\mathrm{mm})$ was calculated as the difference between PP and potential evapotranspiration.

\section{Soil Analysis and Mineral Elements in Soils}

Composed soil samples $(0-30 \mathrm{~cm}$ depth) were analyzed for texture, $\mathrm{pH}$, salinity $\left(\mathrm{dS} \mathrm{m}^{-1}\right)$, organic matter $\left(\mathrm{g} \mathrm{kg}^{-1}\right)$, cation exchange capacity (CEC) $\left(\mathrm{cmol} \mathrm{kg}^{-1}\right)$, and the following available macronutrients: $\mathrm{P}(\mathrm{ppm})$, sodium $(\mathrm{Na})\left(\mathrm{cmol} \mathrm{kg}^{-1}\right)$, $\mathrm{K}\left(\mathrm{cmol} \mathrm{kg}^{-1}\right), \mathrm{Ca}\left(\mathrm{cmol} \mathrm{kg}^{-1}\right)$, and $\mathrm{Mg}\left(\mathrm{cmol} \mathrm{kg}^{-1}\right)$ (SAMLA, 2004).

Available micronutrients and trace elements were extracted from $15 \mathrm{~g}$ of pulverized soil samples with $30 \mathrm{~mL}$ of $0.2 \mathrm{~mol} \mathrm{~L}^{-1}$ EDTA di Na-di $\mathrm{H}_{2} \mathrm{O}$ (Garrabrants and Kosson, 2000). The concentrations of $\mathrm{Fe}, \mathrm{Zn}, \mathrm{Mn}, \mathrm{Cu}, \mathrm{Co}$, and $\mathrm{Cd}$ were measured using flame atomic absorption spectrometry (AAnalyst 100; PerkinElmer, Waltham, MA) (USEPA, 2003). Molybdenum was determined with graphite furnace atomic absorption spectrometry (HGA 900 AAnalyst 400; PerkinElmer), and As was determined with hydride atomic absorption spectrometry (FIAS 400 AAnalyst 100; PerkinElmer) (USEPA, 2003).

\section{Mineral Elements Analysis of Soybean Seeds}

Calcium, K, Mg, P, Na, Fe, Zn, Mn, Mo, Cu, Co, Se, aluminum ( $\mathrm{Al}), \mathrm{Cd}$, and $\mathrm{As}$ were determined in 2-g soybean samples that were digested with $\mathrm{HNO}_{3}$. The minerals were analyzed by inductively coupled plasma-mass spectrometry $(7500 \mathrm{c}$ series; Agilent Technologies, Santa Clara, CA) with a $\mathrm{H}_{2} / \mathrm{He}$ collision cell. National Institute of Standards and Technology standard reference material was used for validation. Detection limits, in $\mathrm{m} \mathrm{kg}^{-1}$ seed dry weight basis, were $3.25 \mathrm{Ca}, 5.75 \mathrm{P}, 86.25$ $\mathrm{K}, 2.18 \mathrm{Mg}, 29.75 \mathrm{Na}, 0.925 \mathrm{Fe}, 0.875 \mathrm{Al}, 0.065 \mathrm{Mn}, 0.068 \mathrm{Zn}$, 
Table 2. Available minerals in soils from eight locations of the Argentine soybean cropland.

\begin{tabular}{|c|c|c|c|c|c|c|c|c|}
\hline \multirow[b]{2}{*}{ Minerals } & \multicolumn{8}{|c|}{ Locations $\dagger$} \\
\hline & BW & $\mathrm{BO}$ & CE & $\mathrm{CA}$ & FA & MA & PA & RQ \\
\hline $\mathrm{P}, \mathrm{ppm}$ & 8.70 & 66.40 & 22.40 & 2.80 & 21.50 & 36.80 & 32.60 & 13.40 \\
\hline $\mathrm{Na}, \mathrm{cmol} \mathrm{kg}^{-1}$ & 0.30 & 1.30 & 0.20 & 0.30 & 0.30 & 0.40 & 0.80 & 0.30 \\
\hline $\mathrm{K}, \mathrm{cmol} \mathrm{kg}-\mathrm{I}$ & 1.90 & 1.60 & 0.30 & 0.20 & 0.70 & 2.30 & 1.70 & 0.50 \\
\hline $\mathrm{Ca}, \mathrm{cmol} \mathrm{kg}^{-1}$ & 12.20 & 6.90 & 6.50 & 16.90 & 5.30 & 10.60 & 16.70 & 7.70 \\
\hline $\mathrm{Mg}, \mathrm{cmol} \mathrm{kg}^{-1}$ & 3.60 & 3.20 & 2.20 & 6.40 & 2.50 & 2.90 & 3.60 & 2.40 \\
\hline $\mathrm{Fe}, \mathrm{mg} \mathrm{kg}^{-1}$ & 189.70 & 134.20 & 546.30 & 138.70 & 246.40 & 150.40 & 94.10 & 193.70 \\
\hline $\mathrm{Cu}, \mathrm{mg} \mathrm{kg}^{-1}$ & 1.80 & 1.50 & 10.40 & 1.40 & 3.00 & 1.90 & 2.10 & 1.30 \\
\hline Zn, mg kg-1 & 1.50 & 1.80 & 71.80 & 0.90 & 3.4 & 125.30 & 1.40 & 0.80 \\
\hline Co, mg kg & 3.20 & 1.20 & 46.30 & 1.10 & 1.50 & 2.50 & 4.50 & 3.60 \\
\hline Mo, $\mathrm{mg} \mathrm{kg}^{-1}$ & 0.06 & 0.07 & 0.09 & 0.09 & 0.15 & 0.48 & 0.32 & 0.29 \\
\hline $\mathrm{Mn}, \mathrm{mg} \mathrm{kg}-\mathrm{I}$ & 196.10 & 96.00 & 1773.60 & 158.60 & 214.00 & 284.10 & 511.60 & 408.60 \\
\hline As, mg kg-I & 0.01 & 0.02 & $N D \ddagger$ & 0.17 & 0.15 & 0.09 & 0.15 & 0.05 \\
\hline $\mathrm{Cd}, \mathrm{mg} \mathrm{kg}^{-1}$ & 0.03 & 0.03 & 0.02 & 0.03 & 0.04 & 0.35 & 0.08 & 0.02 \\
\hline
\end{tabular}

† BO, Bordenave; BW, Barrow; CA, Cerro Azul; CE, Cerrillos; FA, Famailla; MA, Manfredi; PA, Parana; RQ, Reconquista.

$\ddagger$ Not detected under the established conditions.

Table 3. Seed fill climatic conditions at the environments resulted by combining location, year, and sowing date.

\begin{tabular}{|c|c|c|c|c|c|c|}
\hline Locationt & Sowing date $\ddagger$ & Tmxई & $\mathrm{Tा}$ & Tmn\# & SR+t & PP-pEVT㧊 \\
\hline & & & $-{ }^{\circ} \mathrm{C}-$ & 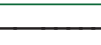 & $\mathrm{MJ} \mathrm{m^{-2 }}$ & $\mathrm{mm}$ \\
\hline \multicolumn{7}{|l|}{2006} \\
\hline \multirow[t]{2}{*}{ BW } & early & 25.0 & 18.4 & 11.9 & 19.7 & 60.3 \\
\hline & late & 23.6 & 17.6 & 11.5 & 17.3 & -17.9 \\
\hline $\mathrm{BO}$ & early & 25.0 & 18.4 & 11.9 & 18.3 & 66.7 \\
\hline \multirow[t]{2}{*}{$C E$} & early & 26.0 & 21.4 & 16.8 & 16.6 & 24.2 \\
\hline & late & 24.3 & 20.2 & 16.0 & 13.4 & 5.5 \\
\hline \multirow[t]{2}{*}{ CA } & early & 30.2 & 25.1 & 19.9 & 22.7 & 92.2 \\
\hline & late & 30.1 & 25.1 & 20.1 & 20.8 & 91.3 \\
\hline FA & late & 26.8 & 22.0 & 17.2 & 11.5 & 6.4 \\
\hline \multirow[t]{2}{*}{ MA } & early & 27.0 & 22.0 & 16.8 & 21.0 & -27.7 \\
\hline & late & 25.6 & 20.8 & 16.0 & 16.1 & 79.0 \\
\hline \multirow[t]{2}{*}{ PA } & early & 26.9 & 22.2 & 17.5 & 16.6 & 337.1 \\
\hline & late & 25.1 & 21.0 & 16.9 & 13.4 & 401.7 \\
\hline \multirow[t]{2}{*}{$\mathrm{RQ}$} & early & 30.1 & 25.0 & 19.9 & 20.4 & 201.3 \\
\hline & late & 28.6 & 23.9 & 19.2 & 17.4 & -15.7 \\
\hline \multicolumn{7}{|l|}{2007} \\
\hline $\mathrm{BO}$ & late & 25.0 & 17.8 & 10.6 & 15.7 & -28.6 \\
\hline \multirow[t]{2}{*}{ CE } & early & 24.7 & 19.5 & 16.0 & 13.3 & 199.7 \\
\hline & late & 24.5 & 19.4 & 16.2 & 14.5 & 47.6 \\
\hline$C A$ & late & 29.7 & 24.6 & 19.5 & 20.1 & 47.5 \\
\hline \multirow[t]{2}{*}{ FA } & early & 29.7 & 24.3 & 19.0 & 17.0 & 158.2 \\
\hline & late & 27.6 & 22.8 & 18.0 & 13.5 & 253.3 \\
\hline \multirow[t]{2}{*}{ MA } & early & 27.4 & 22.1 & 16.7 & 19.2 & 8.3 \\
\hline & late & 25.6 & 19.5 & 13.4 & 15.3 & 30.3 \\
\hline PA & late & 27.3 & 21.1 & 14.9 & 17.6 & -63.0 \\
\hline
\end{tabular}

† BO, Bordenave; BW, Barrow; CA, Cerro Azul; CE, Cerrillos; FA, Famailla; MA, Manfredi; PA, Parana; RQ, Reconquista.

$\ddagger$ Seed fill occurs from the end of January to the beginning of March for early sowing dates and from the end of February to the middle April for late sowing dates.

$\S$ Maximum air temperature.

Tा Mean air temperature.

\# Minimum air temperature

†† Solar radiation

$\ddagger \ddagger$ Precipitation minus potential evapotranspiration. 
Table 4. Mean, minimum, and maximum values of mineral concentrations in two soybean genotypes averaged across environments (location, year, and sowing date).

\begin{tabular}{|c|c|c|c|c|c|c|}
\hline \multirow[b]{2}{*}{ Minerals } & \multicolumn{3}{|c|}{ Specialty soybean } & \multicolumn{3}{|c|}{ Commercial GR† soybean } \\
\hline & Mean & Min. & Max. & Mean & Min. & Max \\
\hline & & & & & & \\
\hline $\mathrm{Ca}$ & 2.99 & 1.76 & 4.84 & 3.93 & 2.07 & 6.77 \\
\hline K & 19.43 & 15.14 & 25.21 & 15.73 & 9.60 & 22.23 \\
\hline $\mathrm{Mg}$ & 2.34 & 1.94 & 2.98 & 2.72 & 2.19 & 3.73 \\
\hline $\mathrm{Na}$ & 0.51 & 0.21 & 0.90 & 0.66 & 0.30 & 1.20 \\
\hline$P$ & 8.69 & 6.34 & 10.72 & 7.45 & 4.98 & 9.89 \\
\hline $\mathrm{Fe}$ & 106.85 & 74.76 & 156.94 & 98.13 & 77.17 & 141.16 \\
\hline $\mathrm{Al}$ & 13.95 & 2.62 & 28.38 & 7.56 & 2.29 & 30.94 \\
\hline $\mathrm{Zn}$ & 43.64 & 23.82 & 85.40 & 48.24 & 24.74 & 140.45 \\
\hline $\mathrm{Cu}$ & 14.32 & 8.05 & 23.82 & 16.24 & 9.66 & 24.83 \\
\hline$M n$ & 38.34 & 21.70 & 70.05 & 41.00 & 17.24 & 100.51 \\
\hline Mo & 7.39 & 0.65 & 33.30 & 5.25 & 0.68 & 19.07 \\
\hline$C d$ & 0.04 & 0.01 & 0.11 & 0.04 & 0.02 & 0.09 \\
\hline As & $N D \ddagger$ & - & - & ND & - & - \\
\hline Co & 139.04 & 39.23 & 430.20 & 206.46 & 60.90 & 536.00 \\
\hline $\mathrm{Se}$ & 70.81 & 1.40 & 374.40 & 64.34 & ND & 413.30 \\
\hline
\end{tabular}

† Glyphosate-resistant.

$\ddagger$ Not detected.

$0.001 \mathrm{Cu}, 0.009 \mathrm{Co}, 0.055 \mathrm{As}$, and $0.012 \mathrm{Cd}$. Selenium was determined by digesting samples with a mixture of nitric acid, hydrochloric acid, and magnesium nitrate (Davis et al., 2001). Hydride generation was performed using an automatic flow injection hydride generator coupled to an atomic absorption spectrophotometer (PinAAcle 900T; PerkinElmer).

\section{Statistical Analysis}

Linear mixed models (West et al., 2007) were fitted to estimate the environmental effect on minerals: the "cultivar" (specialty vs. commercial cultivar) effect was considered as fixed, and "environment" (combination of location, sowing date, and year) as well as cultivar $\times$ environment interaction effects were regarded as random. The significance of variance components were tested by likelihood ratio tests (Molenberghs and Verbeke, 2007). P values were corrected by Bonferroni criteria $(\alpha=0.05)$. The relative environmental variance (REV) was expressed as the percentage of the environmental standard deviation to the mean mineral concentration. The ratio between mean mineral concentrations of soybean types was calculated. Partial least squares (PLS) regressions (Aastveit and Martens, 1986) were accomplished. The plot suggested by the PLS approach was used to identify the climatic covariables explaining particular trait $\times$ environment interactions.

Regression trees (RTs) (Breiman et al., 1984) were fitted to identify climatic thresholds for mineral concentrations in seeds. The response variable (each mineral element) was modeled as a piecewise constant function of the climatic variable. Data were first split into two subsets based on a threshold value of the predictor variable that resulted in the greatest increase/decrease in explained variance of the response variable. Each subset, or node, was then analyzed independently using the same binary partitioning procedure, with a split performed only if the resulting model exceeded predefined criteria of improvement. Environmental variables splitting early tree nodes were used to define optimum weather conditions (OWC) for each mineral. The predicted response value for that pruned tree was compared with the overall trait mean with a Fisher test at $\alpha=0.05$. Finally, multiple Pearson correlations between minerals and soil features were calculated at the $5 \%$ significance level $(\alpha=0.05)$. InfoGen (Balzarini and Di Rienzo, 2012) software was used to accomplish the statistical analysis.

\section{RESULTS AND DISCUSSION}

\section{Environment Effect on Soybean Minerals}

The soil properties and soil mineral composition of each location are detailed in Tables 1 and 2. The soils were suitable for agricultural activity with no limitations (Table 1). Zinc, Cd, and As in the used soils were under the maximum allowable concentrations for agricultural production $\left(600,3\right.$, and $20 \mathrm{mg} \mathrm{kg}^{-1}$, respectively) according to Argentinean Law 24051 (Argentinean National Law, 1992). The values of minimum, mean, and maximum air temperatures; solar radiation; precipitation; and hydric balance data for the studied environments defined by the combination of location, crop year, and sowing date are shown in the Table 3. These environmental features are averages of eight sowing locations, $2 \mathrm{yr}$, and two sowing dates.

The concentration of Se and Mo in soybean seeds showed the greatest variation, followed by $\mathrm{Ca}, \mathrm{Na}, \mathrm{Al}, \mathrm{Zn}, \mathrm{Cu}, \mathrm{Mn}, \mathrm{Co}$, and $\mathrm{Cd}$ (Table 4). These mineral concentrations also differed among the analyzed soils (Table 2). The mineral composition in soybeans reflects their content in the soil (Wauchope, 1978), even though soils might not be the unique source of variation because the climatic variables during the growing season may influence the mineral intake from soils (Bennie et al., 1982; Jaureguy et al., 2013). The factor calculated as REV showed the total variance explained by the environmental effect (Table 5). A high and significant contribution of the environment $(p<0.0036)$ occurred in terms of 


\begin{tabular}{|c|c|c|c|c|c|}
\hline Mineral & Mean & Min. & Max. & REV $\dagger$ & $S / C \ddagger$ \\
\hline & & $\mathrm{g} \mathrm{kg}^{-1}$ & & $\%$ & \\
\hline $\mathrm{Ca}$ & 3.44 & 1.76 & 6.77 & $24.42 *$ & $0.76 *$ \\
\hline $\mathrm{K}$ & 17.68 & 9.60 & 25.21 & 6.22 & 1.24* \\
\hline $\mathrm{Mg}$ & 2.52 & 1.94 & 3.73 & $7.54 *$ & $0.86^{*}$ \\
\hline $\mathrm{Na}$ & 0.58 & 0.21 & 1.20 & 0.00 & $0.77 *$ \\
\hline \multirow[t]{2}{*}{$P$} & 8.10 & 4.98 & 10.72 & 4.94 & $1.17 *$ \\
\hline & & $\mathrm{mg} \mathrm{kg}^{-}$ & & $\%$ & \\
\hline $\mathrm{Fe}$ & 102.73 & 74.76 & I56.94 & $12.04 *$ & 1.09 \\
\hline $\mathrm{Al}$ & 10.93 & 2.29 & 30.94 & 0.01 & I.85* \\
\hline $\mathrm{Zn}$ & 45.84 & 23.82 & 140.45 & $38.94 *$ & 0.90 \\
\hline $\mathrm{Cu}$ & 15.23 & 8.05 & 24.83 & $13.66 *$ & 0.88 \\
\hline$M n$ & 39.59 & 17.24 & $100.5 \mid$ & $29.30 *$ & 0.94 \\
\hline Mo & 6.38 & 0.65 & 33.30 & $99.84 *$ & I.4I \\
\hline $\mathrm{Cd}$ & 0.04 & 0.01 & 0.11 & 25.00 & 1.00 \\
\hline \multirow[t]{2}{*}{ As } & ND§ & - & - & - & - \\
\hline & & $\mu \mathrm{g} \mathrm{kg-}$ & & $\%$ & \\
\hline Co & 170.24 & 39.20 & 536.00 & $58.82 *$ & 0.70 \\
\hline $\mathrm{Se}$ & 67.53 & 0.00 & 413.30 & $131.43 *$ & 1.17 \\
\hline
\end{tabular}

* Significant at the 0.05 probability level.

† Environmental variance relative to the mean for each mineral concentration.

$\ddagger$ Specialty/commercial soybean ratio of averaged values.

$\S$ Not detected.

the total variance for Se and Mo contents, with 131.43 and $99.84 \%$

REV, respectively (Table 5). The REVs for Co (59\%), Zn (39\%),

Mn (29\%), Ca (24\%), Cu (14\%), Fe (12\%), and Mg (8\%) (Table 5)

were significantly lower. These low REVs suggested relatively more stable concentrations across environments. Similarly, no variations in Fe content in soybeans from different sowing dates were previously reported by Jaureguy et al. (2013). Iron deficiency is a concern throughout the world. Soybeans represent a good source to address at least an adequate intake (Gibson and Mullen, 2001).

Wiersma and Moraghan (2013) reported minor differences in element concentrations. In this study, the minor differences in $\mathrm{Fe}, \mathrm{Zn}, \mathrm{Cu}, \mathrm{Mn}, \mathrm{Mo}, \mathrm{Co}$, and Se were primarily attributed to the effect of the location and environment (Table 5). To achieve a better understanding of this variation, PLS regressions were performed. The orthogonal representations are given in Fig. 1, where climatic variables and soil parameters were considered as covariables of the projected regressions of the mineral residues from the linear mixed models. Maximum, mean, and minimum air temperatures were highly correlated (data not shown). Therefore, only mean air temperature was used for the PLS regression (Fig. 1). The effect of the environment on minerals in soybeans was further investigated by RT, which showed climatic thresholds with significant differences in elements concentrations (Table 6; Fig. 2). Also in this study, optimum weather conditions (OWC) were defined as the climatic variables that maximize or minimize the content for each mineral element in soybeans (Table 6).

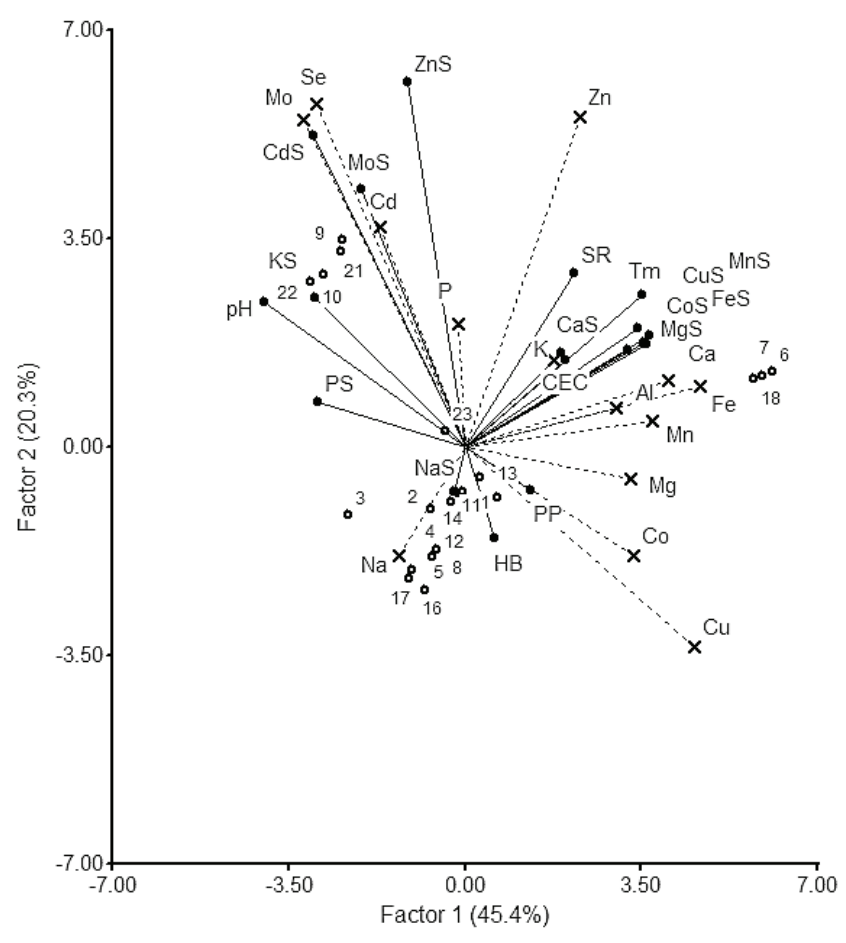

Fig. I. Orthogonal representation of the projections of climatic and soil variables of partial least squares regressions in mineral concentrations of soybeans. Empty dots represent environments. Predictors are indicated by vectors ended with filled dots: mean daily air temperature (Tm), precipitation (PP), hydric balance (HB), solar radiation (SR), cation exchange capacity (CEC), soil pH, and available minerals in soil (CaS, KS, PS, MgS, NaS, MoS, MnS, FeS, ZnS, CuS, CoS, CdS, and AsS). Predicted response variables (minerals in seeds) are shown with star-ended vectors: $\mathrm{K}, \mathrm{P}, \mathrm{Ca}, \mathrm{Mg}, \mathrm{Na}, \mathrm{Fe}, \mathrm{Zn}, \mathrm{Al}, \mathrm{Mn}, \mathrm{Cu}, \mathrm{Mo}, \mathrm{Co}$, Se, and Cd. Environments: I, Barrow I, I (first year, early sowing date); 2, Barrow I, 2 (late sowing date); 3, Bordenave, I, I; 4, Cerrillos, I, I; 5, Cerrillos, I, 2; 6, Cerro Azul, I, I; 7, Cerro Azul, I, 2; 8, Famaillá, I, 2; 9, Manfredi, I, I; I0, Manfredi, I, 2; II, Paraná, I, I; I2, Paraná, I, 2; I3, Reconquista I, I; I4, Reconquista, I, 2; I5, Bordenave, 2, 2; 16, Cerrillos, 2, I; I7 Cerrillos, 2, 2; I8, Cerro Azul, 2, 2; 19, Famaillá, 2, I; 20, Famaillá, 2, 2; 21, Manfredi, 2, I; 22 Manfredi, 2, 2; 23, Paraná, 2, 2. 
Table 6. Overall mean of mineral concentration and optimum weather conditions for maximizing mineral concentrations in soybean seeds.

\begin{tabular}{|c|c|c|c|c|c|c|c|}
\hline \multirow[b]{2}{*}{ Minerals } & \multicolumn{5}{|c|}{ OWCt } & \multicolumn{2}{|c|}{ Mineral means } \\
\hline & Tmx‡ & $\mathrm{T} \oint$ & Tmnף & PP\# & SR+t & OWC & Overall mean \\
\hline & 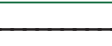 & $-{ }^{\circ} \mathrm{C}-$ & 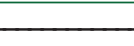 & $\mathrm{mm}$ & $M j \mathrm{~m}^{-2}$ & 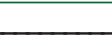 & -1 \\
\hline $\mathrm{Ca}$ & $>30.1 *$ & & $>17.1^{*}$ & & & 5.10 & 3.44 \\
\hline K & & $>20.5^{*}$ & & & $\leq 14.8$ & 20.75 & 17.68 \\
\hline $\mathrm{Mg}$ & $>30.1 *$ & & $>17.1 *$ & & & 3.14 & 2.52 \\
\hline $\mathrm{Na}$ & $\leq 26.3 *$ & & & & & 0.62 & 0.57 \\
\hline$P$ & $>27.1$ & & & & & 8.60 & 8.11 \\
\hline & & & & & & & 8 \\
\hline $\mathrm{Fe}$ & $>28.0 *$ & & & & & 122.98 & 102.73 \\
\hline $\mathrm{Al}$ & $\leq 30.1$ & & $>16.7^{*}$ & & & 13.35 & 10.93 \\
\hline $\mathrm{Zn}$ & & & & & $>18.1 *$ & 53.52 & 45.84 \\
\hline $\mathrm{Cu}$ & & $>22.1 *$ & & & & 19.69 & 15.23 \\
\hline$M n$ & $>30.1 *$ & & $>17 . I^{*}$ & & & 71.52 & 39.59 \\
\hline Mo & & & & $\leq 179.4$ & & 18.79 & 6.38 \\
\hline $\mathrm{Cd}$ & & & $>17.0 *$ & & & 0.03 & 0.04 \\
\hline Co & $>28 *$ & & & & & 309.97 & 156.10 \\
\hline $\mathrm{Se}$ & & & & $\leq 188.8$ & $>18.4^{*}$ & 245.99 & 63.11 \\
\hline
\end{tabular}

* Significant at the 0.05 probability level.

† Optimum weather conditions.

$\ddagger$ Maximum air temperature.

$\S$ Mean air temperature.

Tा Minimum air temperature.

\# Precipitation.

†† Solar radiation.
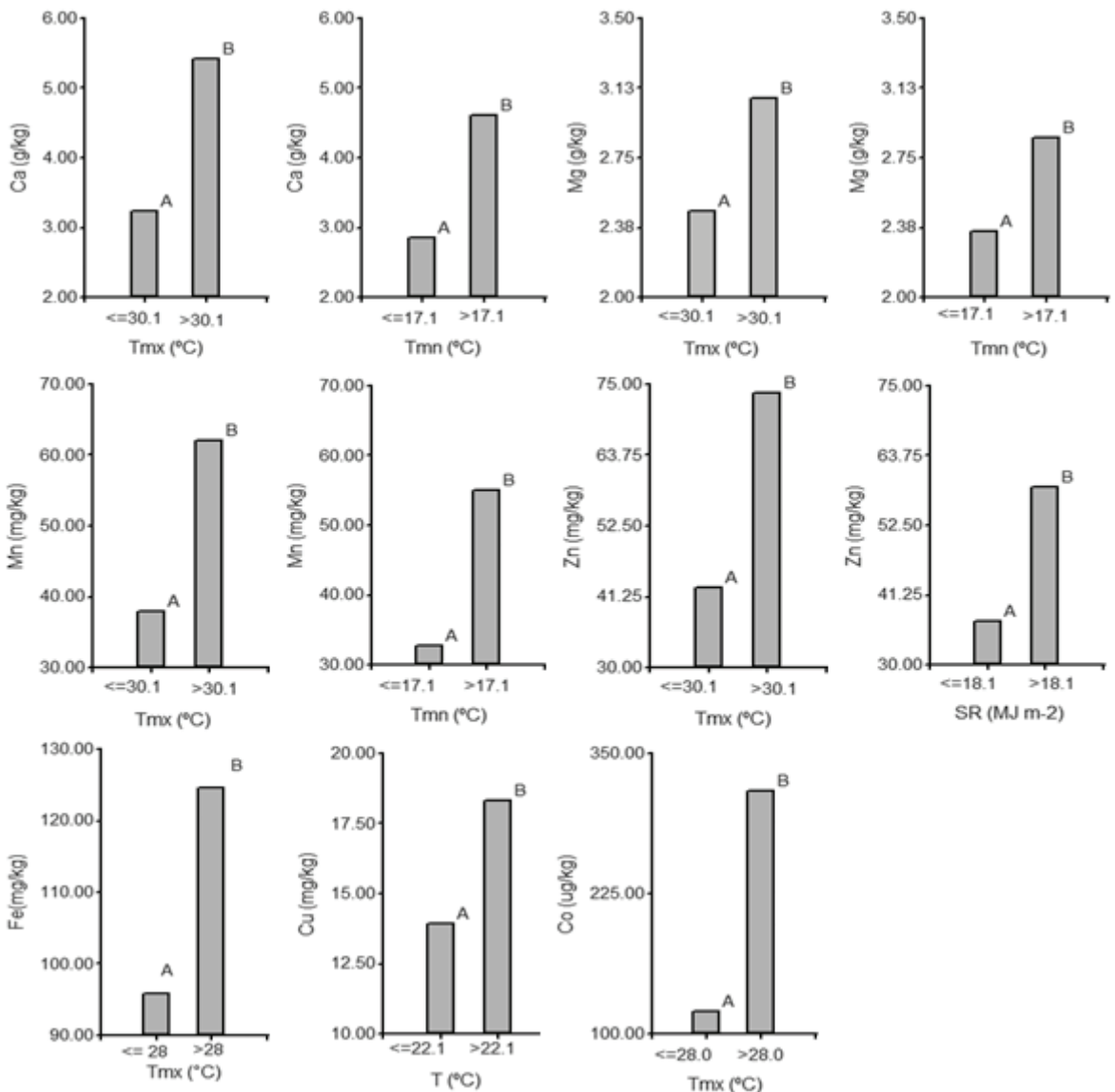

Fig. 2. Differences on mineral concentrations in soybeans $(P \leq 0.00 \mathrm{I})$ after climatic thresholds were applied. Climatic variables were the predictor variables that resulted from splitting data in the regression trees. Climatic variables during the seed filling period (R5-R7): SR, mean daily solar radiation; T, mean daily air temperature; Tmn, mean daily minimum air temperature; and Tmx, mean daily maximum air temperature. 
Maximum values were preferred for the nutritionally necessary elements (Ca, Mg, K, P, Fe, Zn, Cu, Mo, Mn, Co, and $\mathrm{Al}$ ), and minimum values were desired for potentially toxic minerals $(\mathrm{Na}$, As, and $\mathrm{Cd}$ ) or required under regulation. Some differences emerged between the results of the performed regressions due to deviations of the projections (Arroyo et al., 2005). Therefore, only consistent regressions $(\alpha=0.05)$ with the measured variables were explained.

With few exceptions, air temperature was the most influential factor affecting mineral concentrations of the soybeans. Jaureguy et al. (2013) found higher contents of $\mathrm{Ca}, \mathrm{K}, \mathrm{Mg}, \mathrm{Mn}$, and $\mathrm{Fe}$ in soybeans from sowing dates associated with higher air temperature throughout the crop season and during the critical period in the same geographical location. Bellaloui et al. (2011) also observed higher seed Ca concentration in Harosoy isolines affected by increments in the maximum air temperature. Gibson and Mullen (2001) also observed that increments in Ca were accompanied by increments in air temperature to a maximum content at $30^{\circ} \mathrm{C}$. In the present study, the average maximum air temperature was $30.5^{\circ} \mathrm{C}$ (Table 3 ), and the prediction for higher Ca content was at a maximum air temperature over $30.1^{\circ} \mathrm{C}$ (Table 6).

The increase in $\mathrm{Mg}, \mathrm{K}, \mathrm{P}, \mathrm{Fe}, \mathrm{Al}, \mathrm{Mn}, \mathrm{Cu}$, and $\mathrm{Co}$ was also predicted by high air temperatures (Table 6). Significant increments were observed for $\mathrm{Mg}(p<0.0001), \mathrm{K}(p=0.0197), \mathrm{Mn}(p$ $=0.0005), \mathrm{Cu}(p<0.0001)$, and $\mathrm{Co}(p<0.0001)$ for higher air temperatures. Greater concentrations of $\mathrm{Mg}$ and $\mathrm{Mn}$ occurred for maximum air temperatures over $30.1^{\circ} \mathrm{C}$. Sodium was the only mineral that increased when the temperature decreased ( $p=0.0043$ ). Conversely, an increase over $60 \%$ in Na content was previously observed with temperatures over $30^{\circ} \mathrm{C}$ (Gibson and Mullen, 2001). Changes in air temperature had a greater effect on $\mathrm{Na}$, as suggested by the projections in Fig. 1. A 90 angle formed among the projected vectors for $\mathrm{Mo}, \mathrm{Se}, \mathrm{Cd}$, and $\mathrm{Cu}$ with air temperature, indicating that there is low correlation between these minerals and air temperature. Cadmium and Mo were more closely associated with the soil matrix. However, a significant increase in $\mathrm{Cu}$ and a decrease in $\mathrm{Cd}$ were predicted by air temperature thresholds (Table 6). A higher Fe $(p<0.0001)$ in soybeans resulted from maximum air temperatures over $28^{\circ} \mathrm{C}$. Contrarily, Bellaloui et al. (2011) reported higher Fe content in soybeans exposed to lower temperatures.

Solar radiation was closely correlated with air temperature (Fig. 1). Solar radiation was a good variable after air temperature for node formation on splitting data by RT for predicting changes in mineral concentration (Table 6). Significantly higher $\mathrm{Zn}(p<0.0001)$ and $\mathrm{Se}(p=0.0088)$ contents resulted when $\mathrm{SR}$ was over 18.1 and $18.4 \mathrm{MJ} \mathrm{m}^{-2}$, respectively. Assuming no significant differences in the efficiency use of radiation and radiation interception, higher total incoming solar radiation produces a higher biomass; therefore, it was presumed that more nutrients are translocated to the seeds (Bennie et al., 1982). Significant differences $(p<0.05)$ in $\mathrm{Ca}, \mathrm{Mg}, \mathrm{Mn}, \mathrm{Fe}$, and $\mathrm{Zn}$ concentration were observed for the SR $18.1 \mathrm{MJ} \mathrm{m}^{-2}$ threshold and air temperature thresholds (Table 6). This study confirmed that there was a high correlation between SR and air temperature (Fig. 1).

Bellaloui et al. (2011) demonstrated that soybeans have higher $\mathrm{P}$ content when the seeds grow under irrigation conditions. In the present study, P in soybeans was not correlated with hydric balance or PP. Only changes in Mo and Se were predicted by changes in PP (Table 6). Mineral concentration over the proposed thresholds of PP was not statistically significant $(p>0.05)$.

Soil $\mathrm{pH}$ reaction affects the availability of plant nutrients and their likeliness to be absorbed, transported via the xylem, and accumulated in the seed via the phloem (Jensen, 2010). Pearson correlation coefficients were calculated, and significant correlations were found $(p<0.05)$ between the mineral concentration in seeds and the soil's CEC and $\mathrm{pH}$. Significant negative correlations were found between soil $\mathrm{pH}$ and the individual mineral concentrations of $\mathrm{Ca}, \mathrm{Mg}$, Fe, $\mathrm{Al}, \mathrm{Cu}, \mathrm{Mn}$, and $\mathrm{Co}$ in seeds. Positive significant correlations between soil $\mathrm{pH}$ and the concentrations of $\mathrm{Mo}$, Se, and $\mathrm{Cd}$ in seeds were also found. Some of these correlations were consistent with the predicted projections of the PLS regressions (Fig. 1); that is, the projections for $\mathrm{Cu}$ in seed and soil $\mathrm{pH}$ followed opposite directions (an almost $180^{\circ}$ angle was formed between their vectors), and Mo in seeds and soil $\mathrm{pH}$ followed a similar direction, placed together on the upper left quadrant. A slightly acidic $\mathrm{pH}$ soil solution favors the availability of most trace elements to plants except for Mo, whose increased availability is observed in moderately alkaline soils (Jensen, 2010). The levels of Mo in soybeans were also closely correlated with Mo availability in the soil matrix (Fig. 1). Soil from $\mathrm{BO}$ had a $\mathrm{pH}$ value close to soil from MA (Table 1), but Mo content in the soil differed significantly between the mentioned locations (Table 2). A similar result was observed for $\mathrm{Cd}$. Selenium in seeds was also high and positively correlated with soil $\mathrm{pH}$, in agreement with the projections of Fig. 1. Zhao et al. (2009) extracted a higher content of available Se from soils with higher $\mathrm{pH}$. Potassium and $\mathrm{Zn}$ showed no significant correlations with soil $\mathrm{pH}$. Potassium, one of the major plant nutrients that showed the largest concentration in soybeans, appears to be less affected by soil $\mathrm{pH}$. Finally, $\mathrm{Zn}$ was significantly correlated with soil CEC.

\section{Genotype Effect on Soybean Minerals}

Although cultivar comparison was not the aim of the present study, the mineral element ratio between specialty and commercial soybeans (Table 5) was calculated as a parameter to detect genotype differences. Previous studies suggested that the genotypic background has a stronger effect on seed mineral concentrations than the environment's effect (Bellaloui et al., 2011). Iron content was significantly higher in the specialty soybean than in the commercial transgenic glyphosate-resistant soybeans. Calcium, $\mathrm{Mg}$, and $\mathrm{Na}$ concentrations were significantly lower in the specialty soybeans than in the commercial soybeans (specialty/commercial ratio $<1$ at $\alpha=0.05$ ) (Table 5). These traits make specialty soybeans interesting because Fe in seeds is nutritionally important for human diets, and low Ca content is desired for tofu production. Also, it was observed that K, P, and Al were significantly higher on average in the specialty soybeans than in the commercial soybeans. The differences between soybean varieties were consistent across the 20 tested environments.

This is one of the few studies researching changes in the concentrations of soybean minerals affected by the environment during seed fill. Mineral composition in seeds is becoming a concern for breeders and for the food/feed industry because vegetables are the main source of minerals for human and animal nutrition. The concentrations of minerals in soybeans were affected not only by the concentration of minerals in soils and soil $\mathrm{pH}$ but also by the climatic conditions (e.g., air temperature and solar radiation) governing during the crop seed filling period. Air 
temperature and soil $\mathrm{pH}$ have the strongest effect on soybean mineral concentration. Higher air temperature during the seed filling period favored $\mathrm{Ca}, \mathrm{Mg}, \mathrm{P}, \mathrm{Fe}, \mathrm{Zn}$, and Co concentrations in soybeans. Molybdenum and $\mathrm{Cd}$ in the seeds were correlated with their availability in the soils. Findings from this study bring a better understanding of the variability on mineral concentration in soybeans as affected by climatic and soil variables.

\section{ACKNOWLEDGMENTS}

This work was supported by INTA (Instituto Nacional de Tecnología Agropecuaria) program number PNCER024022 (2006-2009) and CONICET (Consejo Nacional de Investigaciones Científicas y Técnicas) through scholarships to C.G. Marioli Nobile and F.M. Aguate. The authors thank Fernando Garcia, Ph.D. (IPNI), and Omar Bachmeier, Ph.D. (UNC-FCA), for their encouragement and unbiased help on the soil data interpretation and Agustin Martellotto for his critical reading of this manuscript and his valuable contribution to the English revision.

\section{REFERENCES}

Aastveit, H., and H. Martens. 1986. ANOVA interactions interpreted by partial least squares regression. Biometrics 42:829-844. doi:10.2307/2530697

Argentinean National Law. 1992. Residuos peligrosos. Decreto Nacional 831/93. http://fracking.cedha.net/wp-content/uploads/2013/09/ RESIDUOS-PELIGROSOS-DECRETO-831-93-LEY-24051-.pdf (accessed 26 Oct. 2015).

Arroyo, A., C. Bruno, J.Di Rienzo, and M. Balzarini. 2005. Árboles de expansión mínimos: Ayudas para una mejor interpretación de ordenaciones en bancos de germoplasma. (In Spanish, with English abstract). Interciencia 30(9):51-63.

Balzarini, M.G., and J.A. Di Rienzo. 2012. InfoGen: Statistical software for genetic data. 2012 ed. Universidad Nacional de Córdoba, Córdoba, Argentina. www.info-gen.com.ar/ (accessed 10 Aug. 2015).

Bellaloui, N., J.R. Smith, A.M. Gillen, and J.D. Ray. 2011. Effect of maturity, genotypic background, and temperature on seed mineral composition in near-isogenic soybean lines in the early soybean production system. Crop Sci. 51:1161-1171. doi:10.2135/cropsci2010.04.0187

Bennie, A.T.P., W.K. Mason, and H.M. Taylor. 1982. Responses of soybeans to two row spacing and two soil water levels: III. Concentration, accumulation and translocation of 12 elements. Field Crops Res. 5:31-43. doi:10.1016/0378-4290(82)90004-1

Bhardwaj, H.L., A.A. Hamama, M. Rangappa, J.M. Joshi, and V.T. Sapra. 2007. Mineral composition of tofu made from twelve soybean genotypes grown at three locations in USA. World J. Agric. Sci. 3(2):140-144.

Breiman, L., J. Friedman, R. Olshen, and C. Stone. 1984. Classification and regression trees. Wadsworth, Belmont, CA.

Carrera, C., M.J.Martínez,J.Dardanelli, and M.Balzarini.2011.Environmental variation and correlation of seed components in nontransgenic soybeans: Protein, oil, unsaturated fatty acids, tocoferols, and isoflavones. Crop Sci. 51:800-809. doi:10.2135/cropsci2010.06.0314

Chen, W., L. Li, A.C. Chang, L. Wu, R.L. Chaney, R. Smith, and H. Ajwa. 2009. Characterizing the solid- solution partitioning coefficient and plant uptake factor of As, $\mathrm{Cd}$, and $\mathrm{Pb}$ in California croplands. Agric. Ecosyst. Environ. 129(1-3):212-220. doi:10.1016/j.agee.2008.09.001

Corguinha, A.P.B., G.A. de Souza, V.C. Gonçalves, C. de Andrade Carvalho, W.E.A. de Lima, F.A. Dias Martins, C.H. Yamanaka, E.A.B. Francisco, and L.R.G. Guilherme. 2015. Assessing arsenic, cadmium, and lead contents in major crops in Brazil for food safety purposes. J. Food Compos. Anal.37:143-150. doi:10.1016/j.jfca.2014.08.004
Davis, C.D., H. Zeng, and J.W. Finley. 2001. Selenium-enriched broccoli decreases intestinal tumorigenesis in multiple intestinal neoplasia mice. J. Nutr. 132(2):307-309.

Fehr, W.R., and C.E. Caviness. 1977. Stages of soybean development. Special Report 80. Iowa State Univ., Ames, IA.

Garrabrants, A.C., and D.S. Kosson. 2000. Use of a chelating agent to determine the metal availability for leaching from soils and wastes. Waste Manag. 20:155-165. doi:10.1016/S0956-053X(99)00326-8

Gibson, L.R., and R.E. Mullen. 2001. Mineral concentrations in soybean seeds produced under high day and night temperature. Can. J. Plant Sci. 81:595-600. doi:10.4141/P00-177

Graham, R.D., R.M. Welch, D.A. Saunders, I. Ortiz-Monasterio, H.E. Bouis, M. Bonierbale, et al. 2007. Nutritious subsistence food systems. Adv. Agron. 92:1-74. doi:10.1016/S0065-2113(04)92001-9

Jaureguy, L.M., F. Ledesma Rodríguez, L. Zhang, P. Chen, K. Brye, D. Oosterhuis, et al. 2013. Planting date and delayed harvest effects on soybean seed composition. Crop Sci. 53:2162-2175. doi:10.2135/ cropsci2012.12.0683

Jensen, T.L. 2010. Soil pH and the availability of plant nutrients. Plant Nutrition Today. www.ipni.net/pnt (accessed 1 June 2015).

Knothe, G., and R.O. Dunn. 2003. Dependence of oil stability index of fatty compounds on their structure and concentration and presence of metals. J. Am. Oil Chem. Soc. 80(10):1021-1026. doi:10.1007/s11746-003-0814-x

Lavado, R.S. 2006. Concentration of potentially toxic elements in field crops grown near and far from cities of the Pampas (Argentina). J. Environ. Manage. 80(2):116-119. doi:10.1016/j.jenvman.2005.09.003

Molenberghs, G., and G. Verbeke. 2007. Likelihood ratio, score, and Wald tests in a constrained parameter space. Am. Stat. 61(1):22-27. doi:10.1198/000313007X171322

Rayman, M. 2012. Selenium and human health (a review). Lancet 379(9822):1256-1268. doi:10.1016/S0140-6736(11)61452-9

SAMLA. (Sistema de Apoyo Metodológico a los Laboratorios de Suelos, Agua, Vegetales y Enmiendas Orgánicas). 2004. In: Laboratory methodologies: A review. [CD]. Secretaría de Agricultura, Ganadería, Pesca y Alimentos (SAGPyA), Argentina.

USEPA. 2003. Test methods: Method 3050b.www3.epa.gov/epawaste/hazard/ testmethods/sw846/pdfs/3050b.pdf (accessed 28 Oct. 2015)

Wauchope, R.D. 1978. Selenium and arsenic levels in soybeans from different production regions of the United States. J. Agric. Food Chem. 26(1):226228. doi:10.1021/jf60215a072

Welch, R.M., and R.D. Graham. 1999. A new paradigm for world agriculture: Meeting human needs productive, sustainable, nutritious. Field Crops Res. 60:1-10. doi:10.1016/S0378-4290(98)00129-4

West, B.T., K.B. Welch, and A.T. Galecki. 2007. Linear mixed models: A practical guide using statistical software. Chapman and Hall CRC Press, New York.

Wiersma, J.V., and J.T. Moraghan. 2013. Within-seed distribution of selected mineral elements among soybean genotypes that vary in iron efficiency. Crop Sci. 53:2051-2062. doi:10.2135/cropsci2012.10.0599

Yoshikawa, Y., P. Chen, B. Zhang, A. Scaboo, and M. Orazaly. 2014. Evaluation of seed chemical quality traits and sensory properties of natto soybean. Food Chem. 153(15):186-192. doi:10.1016/j.foodchem.2013.12.027

Zhao, F.J., H.Y. Su, S.J. Dunham, M. Rakszegi, Z. Bedo, S.P. McGrath, and P.R. Shewry. 2009. Variation in mineral micronutrient concentrations in grain of wheat lines of diverse origin. J. Cereal Sci. 49:290-295. doi:10.1016/j. jcs.2008.11.007 